\title{
Mechanical Parameters of Deep-Buried Coal Goaf Rock Mass Based on Optimized GSI Quantitative Analysis
}

\author{
Qingqiu Wang, ${ }^{1,2}$ Mo Xu $\mathbb{D D}^{1}{ }^{1}$ Yunhui Zhang $\left(\mathbb{D},{ }^{3}\right.$ Xinyu Cen, ${ }^{1}$ and Xingwang Chang ${ }^{1,2}$ \\ ${ }^{1}$ State Key Laboratory of Geohazard Prevention and Geoenvironment Protection, College of Environment and Civil Engineering, \\ Chengdu University of Technology, Chengdu 610059, China \\ ${ }^{2}$ China Railway Eryuan Engineering Group Co., Ltd., Chengdu 610031, China \\ ${ }^{3}$ Faculty of Geosciences and Environmental Engineering, Southwest Jiaotong University, Chengdu 611756, China \\ Correspondence should be addressed to Mo Xu; xm@cdut.edu.cn
}

Received 18 March 2021; Revised 21 July 2021; Accepted 9 August 2021; Published 31 August 2021

Academic Editor: Dezhong Kong

Copyright ( 2021 Qingqiu Wang et al. This is an open access article distributed under the Creative Commons Attribution License, which permits unrestricted use, distribution, and reproduction in any medium, provided the original work is properly cited.

\begin{abstract}
In order to obtain the accurate mechanical parameters of deep-buried coal goaf rock mass, the limitation of geological strength index (GSI) in concealed rock mass is analyzed. Based on the test result and analysis of the current normative standards, the classification indexes of rock mass structural are optimized based on discontinuity distance $d$ and rock mass integrity index $K_{v}$. The ratio of rock mass saturated strength to dry strength, $\eta$, is introduced, quantization formula of structural surface conditions is proposed, and the influence of groundwater and rock types is included in structural surface condition classification. The GSI system is improved to better suit all types of deep-buried and water-rich rock masses. Furthermore, the rock mass disturbance factor $D$ 's quantitative formula is listed according to the Hoek-Brown (HB) criterion. Taking the goaf roof under railway as an example, the parameters of deep-buried rock mass are obtained based on the improved quantitative GSI system and HB criterion. This research provides a scientific reference for achieving geological parameters and engineering designing in goaf areas.
\end{abstract}

\section{Introduction}

There are different types of discontinuities in rock mass with the complex geological process, and mechanical parameters of rock mass are important factors of qualitative evaluation for engineering analysis and design [1]. The foundation stability and cost of project are closely correlated with the mechanical parameters, and parameter estimation of rock mass in the recent research is one of the hot topics $[2,3]$. Now, great achievements have been made in obtaining mechanical parameters of rock mass by scholars. The main methods are theory analysis based on in situ experiment and empirical formula based on test [4]. However, size effect on rock mass in situ test is an unavoidable problem, and largescale in situ test cannot be completely carried out with current test equipment $[5,6]$. It is more necessary and valuable to research the method of achieving deep-buried rock mass mechanical parameters based on field and laboratory tests.
Hoek and Brown proposed the Hoek-Brown (HB) failure criterion in 1980 to estimate intact rock mass strength, and they introduced geological strength index (GSI) and disturbance factor $D$ and proposed the generalized $\mathrm{HB}$ criterion to estimate the jointed rock mass mechanical parameters in 2002 [7]. HB criterion is widely accepted and has been applied in a large number of projects. The GSI value mainly depends on rock mass structure and structural surface conditions. Rock mass structure is determined by classification of the rock mass integrity, structural surface conditions are determined by roughness, weathering, and infilling of the surface, and all factors are qualitatively and subjectively evaluated. Later, many scholars have researched the methods on achieving the GSI value, and rock mass structure can be quantified by the number of joints $J_{v}$ [8]. $J_{v}$ is an important index to evaluate the integrity of rock mass. However, it is difficult to obtain the volumetric joint number of deep-buried rock mass by field measurements; in addition, the influence of groundwater on the rock mass 
mechanical parameters has not been included when the GSI value is estimated.

In order to solve the problem that the volumetric joint number $J_{v}$ of concealed rock mass cannot be obtained by field measurement, Xia et al. [9] established a formula of geological strength index (GSI) by longitudinal wave velocity $V_{p}$ of rock mass, where GSI $=15 V_{p}-7.5$, but this method is proposed on the basis of intact rock mass tests. When growing rock mass fissures are in-filled with groundwater, the wave velocity is larger than that without groundwater, and the GSI value is also larger, which easily leads to the wrong conclusion that the rock mass is more complete than it really is.

The influence of groundwater on rock mass is mainly reflected in lubrication, softening, and chemical erosion of rock mass structural surface. Groundwater can easily soften and alter rock mass structural surface conditions. The crack water pressure can reduce the effective stress and mechanical parameters. However, groundwater has little effect on rock mass structure, which is determined by discontinuities. Therefore, the influence of groundwater on the rock mass GSI can only be considered in the rock mass structural surface conditions. In addition, it can also minimize the error caused by the large wave velocity of broken rock mass filled with groundwater.

\section{Estimation of Rock Mass Mechanical Parameters Based on HB Criterion}

Now, the nonlinear HB criterion for rock masses is widely accepted and has been applied in many projects around the world to estimate the strength and deformation characteristics of heavily jointed rock masses [10]. It also has been widely used in mining engineering $[7,11]$. Rock mass cohesion $C_{m}$, friction angle $\phi_{m}$, and compressive strength $\sigma_{c m}$ can be estimated by the empirical formulas as follows.

$$
\begin{aligned}
& C_{m}=\frac{\sigma_{c i}\left((1+2 a) s+(1-a) m_{b} \sigma_{3 n}\right)\left(s+m_{b} \sigma_{3 n}\right)^{a-1}}{(1+a)(2+a) \sqrt{1+\left(6 a m_{b}\left(s+m_{b} \sigma_{3 n}\right)^{a-1}\right) /(1+a)(2+a)}}, \\
& \phi_{m}=\sin ^{-1} \frac{6 a m_{b}\left(m_{b} \sigma_{3 n}+s\right)^{a-1}}{2(1+a)(2+a)+6 a m_{b}\left(m_{b} \sigma_{3 n}+s\right)^{a-1}}, \\
& \sigma_{3 n}=\frac{0.47 \sigma_{c m}^{0.06}(\gamma H)^{0.94}}{\sigma_{c i}}, \\
& m_{b}=m_{i} \exp \frac{\mathrm{GSI}-100}{28-14 D}, \\
& \sigma_{c m}=\sigma_{c i} \cdot \frac{\left(m_{b}+4 s-a\left(m_{b}-8 s\right)\right)\left(m_{b} / 4+s\right)^{a-1}}{2(1+a)(2+a)}, \\
& \sigma_{t}<\sigma_{3}<\frac{\sigma_{c i}}{4},
\end{aligned}
$$

where $\sigma_{c i}$ is the uniaxial compressive strength of the intact rock mass, $\gamma$ is the unit weight of the rock mass, $H$ is depth of rock mass below surface, $\sigma_{t}$ is the tensile strength of intact rock, $m_{i}$ refers to material constants of intact rock, which can be determined by references $[12,13]$, and $s$ refers to the rock mass material constants, given by

$$
s=\exp \left(\frac{\mathrm{GSI}-100}{9-3 \mathrm{D}}\right) \text {. }
$$

$a$ is rock mass feature factor, given by

$$
a=\frac{1}{2}+\frac{1}{6}\left(\exp \left(\frac{-\mathrm{GSI}}{15}\right)-\exp \left(\frac{-20}{3}\right)\right)
$$

Hoek and Diederichs corrected the deformation modulus of intact rock with modulus ratio and established the empirical formula [14], as follows:

$$
E_{m}=E_{i}\left(0.02+\frac{1-D / 2}{1+\exp ((60+15 D-\mathrm{GSI}) / 11)}\right)
$$

where $E_{m}$ and $E_{i}$ are the jointed and intact rock mass deformation moduli and $D$ is the rock mass disturbance factor, which can be determined by reference [7].

The formulas above are all related to the geological strength index (GSI). How to correctly achieve GSI value is the key to the calculation.

\section{Determination and Optimization of Geological Strength Index (GSI)}

The geological strength index (GSI) value is related to rock mass structure and structural surface conditions and discussed separately below.

3.1. Quantification of Rock Mass Structure. In order to quantify the rock mass structure of the GSI system, Sonmez and Ulusay [15] classified rock mass structure by introducing rock mass volumetric joint number $J_{v}$. On the basis of assuming that rock mass is isotropic, $J_{v}$ is given by

$$
J_{v}=\frac{N_{x}}{L_{x}} \frac{N_{x}}{L_{x}} \frac{N_{x}}{L_{x}}
$$

where $N_{x}, N_{y}$, and $N_{z}$ are the joint numbers along scan lines $\left(L_{x}, L_{y}\right.$, and $\left.L_{z}\right)$ and $L_{x}, L_{y}$, and $L_{z}$ are the lengths along perpendicular direction.

The goaf roof is affected by the stress redistribution after coal excavation, and many cracks develop along rock mass strike and dip. Affected by the force of gravity, the roof rock masses constantly produce bed separation or cracks. Joints and fissures distribute unevenly and irregularly in rock mass, and it is very difficult to measure the joint number of buried rock mass in engineering geological investigation. Fortunately, many scholars found that there is a good correspondence between the volumetric joint number $J_{v}$ and integrity index $K_{v}$ of rock mass based on the extensive field test [16], and the relationship between $J_{v}$ and $K_{v}$ is listed in Table 1 .

According to the corresponding relations between $J_{v}$ and $K_{v}$, the corresponding formula between them can be shown as 
TABLE 1: Relationship between volumetric joint number $J_{v}$ and integrity index $K_{v}$ of rock mass [16].

\begin{tabular}{|c|c|c|c|c|c|}
\hline Volumetric joint number $J_{v}$ (per cubic metre) & $<3$ & $3-10$ & $10-20$ & $20-35$ & $>35$ \\
\hline Integrity index $K_{v}$ & $>0.75$ & $0.75-0.55$ & $0.55-0.35$ & $0.35-0.15$ & $<0.15$ \\
\hline
\end{tabular}

$$
K_{v}=-0.043+0.9 \exp \left(\frac{-J_{v}}{23.5}\right)
$$

The correlation coefficient of function fitting is 0.998 , and they fit well.

Distance and number of discontinuities are important indexes for describing rock mass structure, and various structural characteristics of rock mass are described in detail and quantized in books, such as Standard for Engineering Classification of Rock Mass [16] and Geological Engineering Handbook [17]. Rock mass structure classification according to normative standards is shown in Table 2.

Coal measure strata belong to sedimentary strata; generally, lots of shallow cracks developed in the rock surface are caused by the stress release of denudation, when the ground stress is small and the rock mass structure is not developed. The cracks decrease gradually with increasing depth and thus deep rock mass is intact. Stable coal seam is generally excavated along strike and dip. When the stress of coal roof and floor is released, intact rock will be destroyed by strike and dip discontinuities. As a result, rock mass displacement and bed-separation fractures develop towards goaf. Therefore, the discontinuities of rock mass include dip fractures, strike fractures, bed-separation fractures along the rock mass surface, and primary fractures. Sonmez et al. [18] proposed the method to calculate rock mass volumetric joint number according to joint sets of rock mass surface.

$$
J_{v}=D_{n} \frac{1}{s}
$$

where $D_{n}$ is the rock mass joint set number and $s$ is the average size of rock block or rock slice (in general, it is considered to be equal to the space between joints). Therefore, the rock mass structure can also be classified based on joint set number and the average size of rock block or rock slice. Assuming that the block is cut by the discontinuities and rock masses are made up of many cubes or polyhedrons, the size of rock mass is the distance between discontinuities. Substituting equation (11) into equation (10), the factor $K_{v}$ can be expressed as

$$
K_{v}=0.9 \exp \left(\frac{-D_{n}}{23.5 s}\right)-0.043 .
$$

Now the classification in the standards of tunnel surrounding rock $[16,17]$ is different from the widely used GSI system [10], and it is necessary to refine the structure classification.

In Table 2, rock mass with discontinuity distance larger than $1.0 \mathrm{~m}$ belongs to intact structure, that with discontinuity distance between $1.0 \mathrm{~m}$ and $0.4 \mathrm{~m}$ belongs to blocky structure, and that with discontinuity distance between $0.4 \mathrm{~m}$ and $0.2 \mathrm{~m}$ belongs to very blocky-interlocked structure. Based on the rock mass classification of tunnel [19] and soil classification [20], the fragmented rock larger than $0.06 \mathrm{~m}$ and the pebble larger than $0.02 \mathrm{~m}$ are distinguished from the fractured rock. Pebble with diameter $0.06 \mathrm{~m}$ to $0.02 \mathrm{~m}$ and brecciated rock mass influenced by tectonics and shear stress are also separately classified. So, rock mass with discontinuity distance between $0.2 \mathrm{~m}$ and $0.06 \mathrm{~m}$ belongs to fractured rock, rock mass with discontinuity distance between $0.06 \mathrm{~m}$ and $0.02 \mathrm{~m}$ belongs to extremely fractured rock, and rock mass with discontinuity distance less than $0.02 \mathrm{~m}$ belongs to conglomeratic rock. In European standards [21], the space of discontinuities is distinguished by $0.2 \mathrm{~m}, 0.06 \mathrm{~m}$, and $0.02 \mathrm{~m}$, and the size of rock mass is distinguished by $0.2 \mathrm{~m}$ and $0.06 \mathrm{~m}$, which is basically consistent with the qualitative classification of the GSI system. Therefore, it is reasonable to distinguish discontinuities by $0.2 \mathrm{~m}, 0.06 \mathrm{~m}$, and $0.02 \mathrm{~m}$. The rock mass integrity index $K_{v}$ can be calculated by equation (12). The new rock mass structure classification is shown in Table 3.

3.2. Quantification of Structural Surface Conditions. The rock mass structural surface conditions in the geological strength index (GSI) system involve roughness, weathering, and infilling of structural surface only. Palmstrom [22] quantified the structure surface conditions of rock mass by the three factors above and left out the effect of groundwater. Jiang et al. [23] suggested reducing the GSI value to reflect the influence of groundwater; in this method, the values of structural surface conditions and rock mass structure are reduced in the same proportion. In fact, rock mass structure is determined by the density of discontinuities; groundwater only has an effect on structural surface conditions, and it is inconsistent with the mechanism of groundwater action on rock mass, so this method needs further discussion.

The influence of groundwater on the rock mass mechanical parameters is more obvious, and all the parameters of the eroded rock are reduced to varying degrees [24]. Liu et al. [25] found based on experiment that the uniaxial compressive strength and deformation modulus of saturated argillaceous sandstone are 58.51\% and 51.64\% compared with dry rock mass. Wang et al. [26] experimented and analyzed saturated sandstone samples of different sizes, and the uniaxial compressive strength and deformation modulus are $56.5 \%$ and $45.6 \%$ compared with dry rock samples. Chen et al. [27] analyzed the effect of fissure water on rock mass effective stress based on triaxial test, and the results show that the effective stress decreases with the increasing pressure of crack water; the effective stresses of the specimens are about $59.02 \%$ and $45.17 \%$ of dry specimens with the confining pressures $15 \mathrm{MPa}$ and $30 \mathrm{MPa}$. In this paper, the strength of dry and saturated goaf rock mass is tested and statistically analyzed, and the test results of compressive strength and deformation 
TABLE 2: Rock mass classification of integrity according to normative standards $[16,17]$.

\begin{tabular}{|c|c|c|c|}
\hline Rock mass integrity & Rock mass joint number $J_{v}$ & $\begin{array}{l}\text { Average distance between discontinuities } \\
\qquad(\mathrm{m})\end{array}$ & Rock mass structure \\
\hline Extremely intact rock & $<3$ & $>1.0$ & Intact structure \\
\hline Relatively intact rock & $3-10$ & $1.0-0.4$ & Blocky structure \\
\hline Relatively fractured rock & $10-20$ & $0.4-0.2$ & Very blocky-interlocked structure \\
\hline Fractured rock & $20-35$ & $<0.2$ & Blocky and disturbed structure \\
\hline $\begin{array}{l}\text { Extremely fractured } \\
\text { rock }\end{array}$ & $>35$ & - & $\begin{array}{l}\text { Disintegrated and laminated } \\
\text { structure }\end{array}$ \\
\hline
\end{tabular}

TABLE 3: New rock mass structure classification by $K_{v}$ and distance between discontinuities.

\begin{tabular}{|c|c|c|c|c|}
\hline $\begin{array}{l}\text { Rock mass } \\
\text { integrity }\end{array}$ & $\begin{array}{c}\text { Rock mass } \\
\text { integrity index } \\
K_{v}\end{array}$ & $\begin{array}{l}\text { Average distance between } \\
\text { discontinuities }(\mathrm{m})\end{array}$ & $\begin{array}{l}\text { Number of } \\
\text { structure sets }\end{array}$ & Structure of rock mass \\
\hline $\begin{array}{l}\text { Extremely intact } \\
\text { rock }\end{array}$ & $>0.75$ & $>1.0$ & $1-3$ & $\begin{array}{c}\text { Intact or massive rock with few widely spaced } \\
\text { discontinuities }\end{array}$ \\
\hline $\begin{array}{l}\text { Relatively intact } \\
\text { rock }\end{array}$ & $0.75 \sim 0.55$ & $1.0-0.4$ & $3-4$ & $\begin{array}{l}\text { Blocky rock mass consisting of cubical blocks formed } \\
\text { by } 3-4 \text { intersecting discontinuity sets }\end{array}$ \\
\hline $\begin{array}{l}\text { Relatively } \\
\text { fractured rock }\end{array}$ & $0.55 \sim 0.35$ & $0.4-0.2$ & $3-4$ & $\begin{array}{l}\text { Very blocky-interlocked and partially disturbed mass } \\
\text { with multifaceted angular blocks formed by 3-4 joint } \\
\text { sets }\end{array}$ \\
\hline Fractured rock & $0.35 \sim 0.01$ & $0.2-0.06$ & 4 & Block folded by 4 intersecting discontinuity sets \\
\hline $\begin{array}{l}\text { Extremely } \\
\text { fractured rock }\end{array}$ & $<0.01$ & $0.06-0.02$ & 4 or more & $\begin{array}{c}\text { Disintegrated, poorly interlocked, and heavily broken } \\
\text { rock mass made up of mixture of angular and } \\
\text { rounded rock pieces }\end{array}$ \\
\hline $\begin{array}{l}\text { Conglomeratic } \\
\text { rock mass }\end{array}$ & & $<0.02$ & 4 or more & $\begin{array}{l}\text { Laminated/sheared, with lack of blockiness due to } \\
\text { close spacing of weak schistosity or shear planes }\end{array}$ \\
\hline
\end{tabular}

modulus of shale, sandstone, and limestone are shown in Table 4.

According to Table 4, the saturated compressive strength is $64.9 \%$ to $77.5 \%$ of dry compressive strength, and the saturated deformation modulus is $62.1 \%$ to $86.5 \%$ of dry deformation modulus. The influence of groundwater on rock mass mechanical parameters is not constant for different types of rock masses and geological environments.

The rock mass rating (RMR) system was modified over years and has stood the test of time, and it conformed with the international standards and procedures. So, this paper refers to the RMR system to quantify the influence on structural surface by groundwater. Roughness, weathering, infilling, and groundwater are the main factors which affect the rock mass structural surface conditions. According to Bieniawski's RMR system [28], the full value of roughness, weathering, and infilling is 6 , respectively, and the total value is 18 , a higher value indicating better rock mass conditions. The full effective value of groundwater on structural surface conditions is 15. Assuming that the groundwater influence coefficient on mechanical parameters of the different types and geological environments of rock masses is $\alpha$, the quantitative formula of rock mass structural surface conditions is given by the following formula:

$$
\mathrm{SCR}=R_{r}+R_{w}+R_{f}+\alpha R_{u},
$$

where $R_{r}, R_{w}$, and $R_{f}$ are the roughness, weathering, and infilling of structural surface conditions and $R_{u}$ is the influence of groundwater on structural surface. The values of structural surface conditions are shown in Tables 5 and 6 .

Groundwater and fissure water reduce effective stress of the rock mass and the friction coefficient of rock mass discontinuities, and the ability of rock mass to resist deformation and failure is reduced. The influence of groundwater on rock mass mainly includes two aspects: the weakening of rock mass structure surface conditions and the damage of rock mass caused by the microcracks in rock mass which are caused by groundwater. The micropores and microcracks in rock can cause the change of rock mass structure surface conditions, and the effect is macroscopically manifested as rock mass volume increasing and the mechanical properties decreasing. Experiments have shown that the compressive strength and deformation modulus decrease linearly with the change of rock mass volume caused by micropores and microcracks [29], and the deformation modulus is linearly related to the RMR value [28]. Therefore, it can be assumed that the compressive strength and deformation modulus of rock mass have a linear relationship with the value of the structural surface conditions, and the compressive strength can be given by

$$
\sigma_{c m}=\sigma_{c i} k\left(R_{r}+R_{w}+R_{f}+\alpha R_{u}\right)
$$

where $k$ refers to the coefficients related to discontinuities of rock mass.

If the rock mass is intact without groundwater, the groundwater has no effect on the rock mass, $R_{u}=15$, and the compressive strength of dry intact rock is given by 
TABLE 4: Compressive strength and deformation modulus of shale, sandstone, and limestone.

\begin{tabular}{|c|c|c|c|c|c|}
\hline $\begin{array}{l}\text { Compressive strength and } \\
\text { deformation modulus based on } \\
\text { test }\end{array}$ & $\begin{array}{l}\text { Range value of } \\
\text { dry rock }\end{array}$ & $\begin{array}{l}\text { Average value } \\
\text { of dry rock }\end{array}$ & $\begin{array}{l}\text { Range value of } \\
\text { saturated rock }\end{array}$ & $\begin{array}{l}\text { Average value of } \\
\text { saturated rock }\end{array}$ & $\begin{array}{c}\text { The ratio of saturated } \\
\text { average value to dry average } \\
\text { value }\end{array}$ \\
\hline $\begin{array}{l}\text { Compressive strength of shale } \\
\text { (MPa) }\end{array}$ & $33.8-36.9$ & 35.32 & $17.6-28.3$ & 22.91 & $64.9 \%$ \\
\hline $\begin{array}{l}\text { Deformation modulus of shale } \\
\text { (GPa) }\end{array}$ & $26.2-35.2$ & 33.0 & $11.8-39.9$ & 20.5 & $62.1 \%$ \\
\hline $\begin{array}{l}\text { Compressive strength of } \\
\text { sandstone }(\mathrm{MPa})\end{array}$ & $42.2-58.1$ & 47.76 & $24.9-39.0$ & 31.91 & $66.8 \%$ \\
\hline $\begin{array}{l}\text { Deformation modulus of } \\
\text { sandstone }(\mathrm{GPa})\end{array}$ & $23.7-46.0$ & 34.8 & $10.9-27.1$ & 21.0 & $60.3 \%$ \\
\hline $\begin{array}{l}\text { Compressive strength of } \\
\text { limestone }(\mathrm{MPa})\end{array}$ & 51.9-101.6 & 80.4 & $53.8-85.1$ & 62.3 & $77.5 \%$ \\
\hline $\begin{array}{l}\text { Deformation modulus of } \\
\text { limestone }(\mathrm{GPa})\end{array}$ & $70.0-95.9$ & 84.9 & $61.1-87.3$ & 73.4 & $86.5 \%$ \\
\hline
\end{tabular}

TABLE 5: Values of structural surface conditions $R_{r}, R_{w}$, and $R_{f}$.

\begin{tabular}{lccccc}
\hline Structural surface conditions & & \multicolumn{4}{c}{ Description and value } \\
\hline Roughness $R_{r}$ & Very rough & Rough & Slightly rough & Smooth & Slickensided \\
& 6 & 5 & 3 & 0 & 1 \\
Weathering $R_{w}$ & Unweathered & Slightly weathered & Moderately weathered & Highly weathered & Decomposed \\
Infilling $R_{f}$ & 6 & 4 & 3 & 1 & 0 \\
& None & Hard filling $<5 \mathrm{~mm}$ & Hard filling $>5 \mathrm{~mm}$ & Soft filling $<5 \mathrm{~mm}$ & Soft filling $>5 \mathrm{~mm}$ \\
& 6 & 4 & 2 & 2 & 0 \\
\hline
\end{tabular}

TABLE 6: Value of structural surface conditions $R_{u}$.

\begin{tabular}{lcccc}
\hline Structural surface conditions & \multicolumn{3}{c}{ Description and value } \\
\hline Water inflow per 50 square metre (l/min) & No water & $<10$ & $10-25$ & $25-125$ \\
Ratio (joint water pressure/major principal stress) & 0 & $<0.1$ & $0.1-0.2$ & $0.2-0.5$ \\
General conditions & Dry & Damp & Wet & Dripping \\
Value $R_{u}$ & 15 & 10 & 70.5 & Flowing \\
\hline
\end{tabular}

$$
\sigma_{c m d}=\sigma_{c i} k(18+15 \alpha)
$$

If the rock mass is saturated, $R_{u}=0$, and the compressive strength of saturated intact rock mass is given by

$$
\sigma_{c m s}=18 \sigma_{c i} k \text {. }
$$

Assuming that $\eta_{\sigma}=\left(\sigma_{c m s} / \sigma_{c m d}\right)$, the influence of groundwater on the compressive strength and deformation modulus of rock mass is different, and comprehensive influence $\eta$ can be replaced by the average value of them two.

$$
\begin{gathered}
\eta=\frac{\eta_{\sigma}+\eta_{E}}{2}, \\
\eta_{E}=\frac{E_{c m s}}{E_{c m d}},
\end{gathered}
$$

where $\sigma_{c m s}$ and $\sigma_{c m d}$ are the compressive strengths of saturated and dry intact rock mass and $E_{c m s}$ and $E_{c m d}$ are the deformation moduli of saturated and dry intact rock mass.

Substitute equations (16) and (17) into equation (15):

$$
\alpha=\frac{18(1-\eta)}{15 \eta} .
$$

Substitute equation (19) into equation (13):

$$
\mathrm{SCR}=R_{r}+R_{w}+R_{f}+\frac{18(1-\eta)}{15 \eta} R_{u} .
$$

If the rock mass is intact without groundwater,

$$
\mathrm{SCR}_{\max }=\frac{18}{\eta} \text {. }
$$

Assuming that the maximum quantized value of rock mass discontinuity conditions is 1.0 , the quantized value $K_{\mathrm{SCR}}$ of different rock mass structural surface conditions can be given by

$$
K_{\mathrm{SCR}}=\frac{\eta}{18}\left(R_{r}+R_{w}+R_{f}\right)+\left(\frac{1-\eta}{15}\right) R_{u} .
$$

The new quantitative value sheet of the GSI system is given based on optimized quantification of rock mass 
structure and structural surface conditions. Buried rock mass structure is classified based on the average distance between discontinuities and integrity index $K_{v}$, and the influence of groundwater and different rock types is fully considered in discontinuity condition classifications. The modification can improve the utility of the GSI system. The quantitative value sheet of the improved GSI system is shown in Figure 1.

3.3. Determination of Rock Mass Disturbance Factor. The disturbance factor $D$ is also a very important factor in the $\mathrm{HB}$ criterion, which is mainly used to indicate the degree of rock mass disturbance in blasting or excavation. However, there are only six discontinuous qualitative evaluation values [7]. In addition, the rock mass disturbance factor proposed by Hoek refers to the disturbance of fresh rock mass that is not affected by blasting and excavation because human activities such as blasting and excavation or rock mass weathering only affect the integrity of rock mass surface. So, the rock mass disturbance factor is the damage degree of rock mass caused by the influence of discontinuities. It is necessary to revise the classification of rock mass structure determined by the surface structure affected by blasting, and the classification of rock mass discontinuity conditions determined by weathered discontinuities should also be revised [13]. Therefore, it is necessary to further discuss the value of disturbance factor $D$.

The original stress state of coal roof changes after coal excavation, rock mass is broken under the unbalance stress, and rock mass deformation modulus will decrease; the deformation modulus is closely correlated with rock mass integrity, and the effective area of section decreases with the development of joints and fissures, while it is difficult to measure the effective bearing area of rock mass. Lemaitre [30] proposed the concept of equivalent stress; assuming that the deformation of the damaged material can be represented by effective stress, the strain of the damaged material is given by

$$
\varepsilon^{\prime}=\frac{\sigma \prime}{E}=\frac{\sigma}{(1-D) E_{m}}=\frac{\sigma}{E_{i}} .
$$

Disturbance factor $D$ can be expressed by

$$
D=1-\frac{E_{m}}{E_{i}} \text {. }
$$

According to equation (24), rock mass disturbance factor $D$ can be calculated by the deformation modulus of disturbance and intact rock mass. The deformation modulus of disturbed rock mass is difficult to get by laboratory test and small field tests; however, integrity index $K_{v}$ is the important index widely accepted to evaluate rock mass integrity. Therefore, the deformation modulus of rock mass can be calculated based on the HB criterion and the improved GSI system, which is classified according to rock mass integrity index $K_{v}$. Substituting equation (24) into equation. (6), the formula can be changed as follows:

$$
D=0.98-\frac{1-D / 2}{1+\exp ((60+15 D-\mathrm{GSI}) / 11)} .
$$

GSI can be obtained by the improved GSI system; according to the equation (25), the relationship between disturbance factor $D$ and the geological strength index (GSI) is listed in Table 7.

When GSI in the table is 100 or 0 , the factor $D$ is not 0 or 1 because there are more microfissures in rock mass in nature, and there is no absolutely intact or completely disturbed rock mass. So, the corresponding relationship is reasonable. The relative curve between them is drawn in Figure 2.

According to Figure 2, the factor $D$ of heavily disturbed rock mass changes slowly with the increase of GSI; in other words, in severely jointed rock mass, the disturbance factor $D$ varies in a small range. When the GSI value is 40 to 90 , the factor $D$ is nearly linearly correlated with GSI. The problem of nonuniform quantitative standards is solved, and the rock mass integrity in engineering can be better evaluated.

\section{Application of Improved GSI System}

This paper takes the coal goaf under railway as an engineering case to obtain the rock mass mechanical parameters. The direction of railway is parallel to strike of the stratum. The stratum distribution in this area is relatively stable, mainly including soil layers, shale, sandstone, and limestone. The maximum depth of coal is $140 \mathrm{~m}$, and the strata from top to bottom are described as follows.

Soil with average thickness of $10.0 \mathrm{~m}$ is made of clay and sand. 9 coal is the first coal mined with average thickness of $0.9 \mathrm{~m}$, and the roof is shale with average thickness of $22.0 \mathrm{~m} .11$ coal top roof is shale with average thickness of $10.7 \mathrm{~m}, 11$ coal lower roof is sandstone with average thickness of $24.1 \mathrm{~m}$, and 11 coal is the second coal mined with average thickness of $1.8 \mathrm{~m} .13$ coal top roof is shale with average thickness of $12.8 \mathrm{~m}$, the middle roof is sandstone with average thickness of $22.0 \mathrm{~m}$, the lower roof is limestone with average thickness of $5.5 \mathrm{~m}$, and 13 coal is the third coal mined with average thickness of $1.5 \mathrm{~m} .15$ coal roof is shale with average thickness of $16.0 \mathrm{~m}$, and 15 coal is the fourth coal mined with average thickness of $1.3 \mathrm{~m}$. Lots of joints and fissures developed in rock mass are affected by the coal mined, the length of typically drilled rock is shorter than $30 \mathrm{~cm}$, the rock quality designation is between 28.6 and 51.0, and the coal roofs belong to fractured rock mass. Groundwater has been largely pumped from the mine. Hence, the structural suface is weakly eroded due to the absence of groundwater. The rock mass structural surface conditions are rough, weakly eroded, unfilled, and wet. Disturbance factor $D$ can be calculated with equation (25). According to the improved GSI system, the rock mass quantitative GSI values of all goaf roofs are given in Table 8.

According to equations (1)-(8), based on the results of laboratory test and field test, rock mass mechanical parameters of goaf roofs can be calculated by the $\mathrm{HB}$ criterion, and the results are shown in Table 9.

Rock mass mechanical parameters of compressive strength, deformation modulus, and friction angle from field 


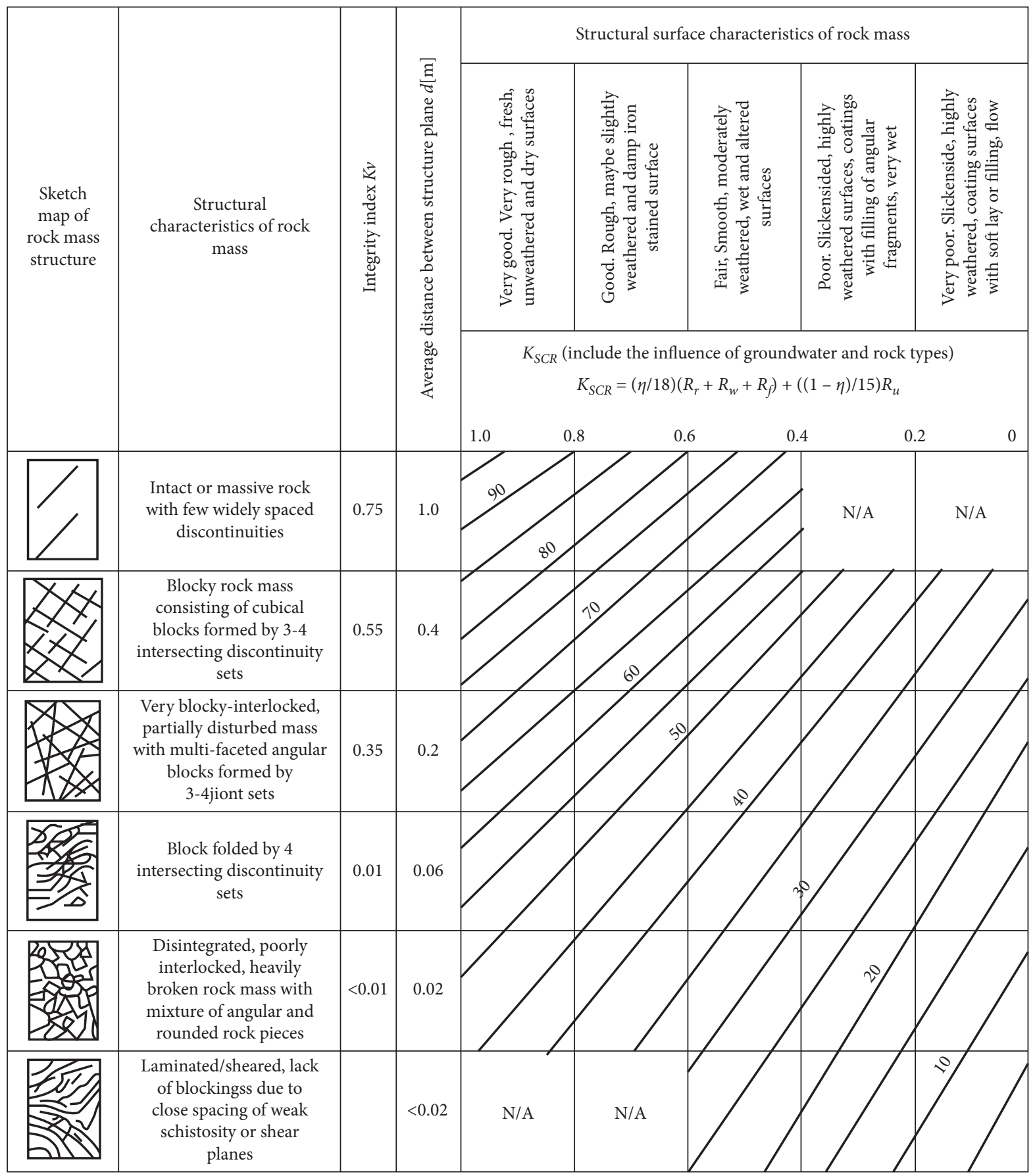

FIgURE 1: The quantitative value sheet of the improved GSI system.

side pressure test are statistically calculated and listed in Table 10. The rock mass mechanical parameters obtained with the method of optimized new GSI system are similar to those from field test.

The excavation of coal has caused surface subsidence, building cracking, and ground collapse. In order to eliminate the main influence on the newly built railway, the goaf areas under railway were filled with cement slurry. Only 9 coal, 11 coal, and 13 coal goafs were filled. After grouting, wave velocity of rock mass was tested again, and the rock mass mechanical parameters required for three-dimensional numerical model are estimated based on the test results, improved GSI system, and HB criterion.

The coal strate having the dip of 18 degree was excavated in the width of $100 \mathrm{~m}$. The three-dimensional numerical analysis model takes railway as the center, the model is $250 \mathrm{~m}$ high, $400 \mathrm{~m}$ long along dip and $200 \mathrm{~m}$ along strike, peripheral and bottom boundaries of model are set as fixed constraints, and the surface is free. The model is divided into 52580 cells. The numerical model is shown in Figure 3.

According to the numerical simulation analysis based on the mechanical parameters in Table 11, the surface 
TABLe 7: Relationship between disturbance factor $D$ and geological strength index (GSI).

\begin{tabular}{lccccccccccc}
\hline GSI & 100 & 90 & 80 & 70 & 60 & 50 & 40 & 30 & 20 & 10 & 0 \\
\hline$D$ & 0.010 & 0.069 & 0.169 & 0.312 & 0.480 & 0.646 & 0.785 & 0.880 & 0.934 & 0.960 & 0.972 \\
\hline
\end{tabular}

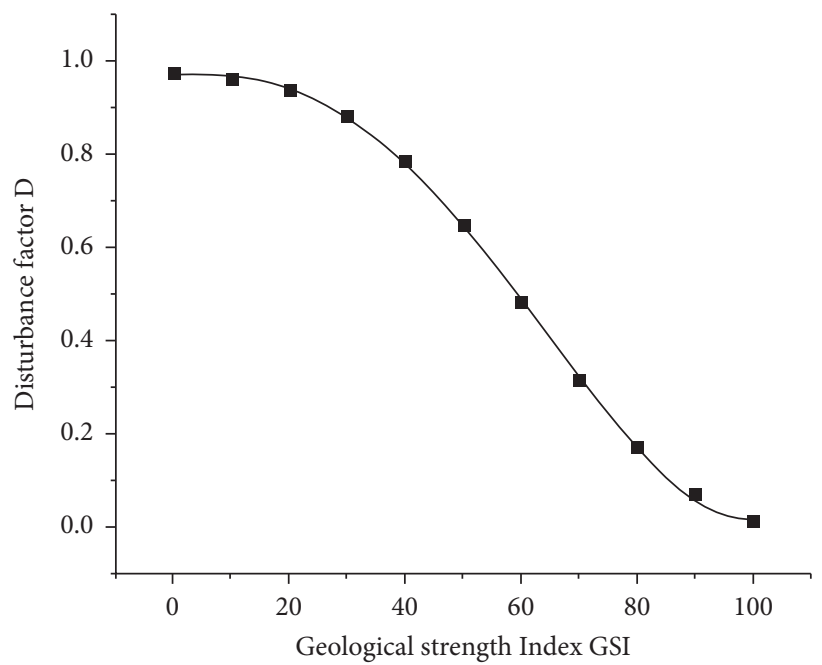

Figure 2: The relative curve between disturbance factor $(D)$ and geological strength index (GSI).

TABLE 8: Quantitative GSI values of all goaf roofs.

\begin{tabular}{|c|c|c|c|c|c|c|}
\hline Roof strata & $K_{v}$ & $d$ & $K_{\mathrm{SCR}}$ & GSI & $D$ & Integrity of rock mass \\
\hline 9 coal roof sandstone and shale & 0.23 & 11.7 & 0.70 & 44.3 & 0.72 & Soft rock, broken rock \\
\hline 11 coal top roof shale & 0.29 & 15.7 & 0.70 & 46.8 & 0.69 & Soft rock, broken rock \\
\hline 11 coal lower roof sandstone & 0.43 & 27.6 & 0.77 & 56.6 & 0.54 & Harder rock, broken rock \\
\hline 13 coal top roof shale & 0.59 & 51.9 & 0.82 & 68.0 & 0.36 & Harder rock, broken rock \\
\hline 13 coal middle roof sandstone & 0.63 & 62.8 & 0.77 & 70.0 & 0.32 & Harder rock, broken rock \\
\hline 13 coal lower roof limestone & 0.34 & 19.5 & 0.80 & 54.0 & 0.58 & Harder rock, broken rock \\
\hline 15 coal roof shale & 0.43 & 27.6 & 0.76 & 56.6 & 0.70 & Soft rock, broken rock \\
\hline
\end{tabular}

TABLE 9: Rock mass mechanical parameters of goaf roof.

\begin{tabular}{|c|c|c|c|c|c|c|c|c|c|c|}
\hline Roof strata & GSI & $\sigma_{c i}$ & $E_{i}$ & $M_{i}$ & $m_{b}$ & $S$ & $a$ & $\begin{array}{l}\text { Compressive strength } \\
(\mathrm{MPa})\end{array}$ & $\begin{array}{c}\text { Deformation modulus } \\
(\mathrm{GPa})\end{array}$ & $\begin{array}{c}\text { Friction angle } \\
\left({ }^{\circ}\right)\end{array}$ \\
\hline $\begin{array}{l}9 \text { coal roof sandstone } \\
\text { and shale }\end{array}$ & 44.3 & 46.9 & 20.6 & 6 & 0.266 & $0.29 \times 10^{-3}$ & 0.508 & 3.12 & 1.49 & 38.5 \\
\hline 11 coal top roof shale & 46.8 & 48.5 & 28.4 & 6 & 0.330 & $0.46 \times 10^{-3}$ & 0.507 & 3.64 & 2.53 & 37.3 \\
\hline $\begin{array}{l}11 \text { coal lower roof } \\
\text { sandstone }\end{array}$ & 56.6 & 75.2 & 21.3 & 9 & 1.074 & $2.8 \times 10^{-3}$ & 0.504 & 10.60 & 4.46 & 49.5 \\
\hline 13 coal top roof shale & 67.9 & 37.1 & 25.2 & 6 & 1.488 & $17.5 \times 10^{-3}$ & 0.502 & 6.97 & 12.06 & 42.7 \\
\hline $\begin{array}{l}13 \text { coal middle roof } \\
\text { sandstone }\end{array}$ & 70.0 & 61.2 & 34.9 & 9 & 2.511 & $23.9 \times 10^{-3}$ & 0.501 & 14.56 & 18.73 & 50.3 \\
\hline $\begin{array}{l}13 \text { coal lower roof } \\
\text { limestone }\end{array}$ & 54.0 & 87.1 & 76.9 & 12 & 1.181 & $1.8 \times 10^{-3}$ & 0.504 & 12.64 & 12.84 & 48.8 \\
\hline 15 coal roof shale & 56.6 & 45.4 & 34.3 & 6 & 0.553 & $1.9 \times 10^{-3}$ & 0.504 & 4.63 & 5.60 & 34.7 \\
\hline
\end{tabular}

TABle 10: Goaf roof mechanical parameters from field test.

\begin{tabular}{lccc}
\hline Roof strata & Compressive strength $(\mathrm{MPa})$ & Deformation modulus $(\mathrm{GPa})$ & Friction angle $\left(^{\circ}\right)$ \\
\hline 9 coal roof sandstone and shale & 3.53 & 1.52 & 40.5 \\
11 coal top roof shale & 3.91 & 2.85 & 39.7 \\
11 coal lower roof sandstone & 11.10 & 12.58 & 48.8 \\
13 coal top roof shale & 7.25 & 19.02 & 41.0 \\
13 coal middle roof sandstone & 14.82 & 12.43 & 51.8 \\
13 coal lower roof limestone & 12.97 & 5.52 & 47.1 \\
15 coal roof shale & 5.13 & 35.6 \\
\hline
\end{tabular}




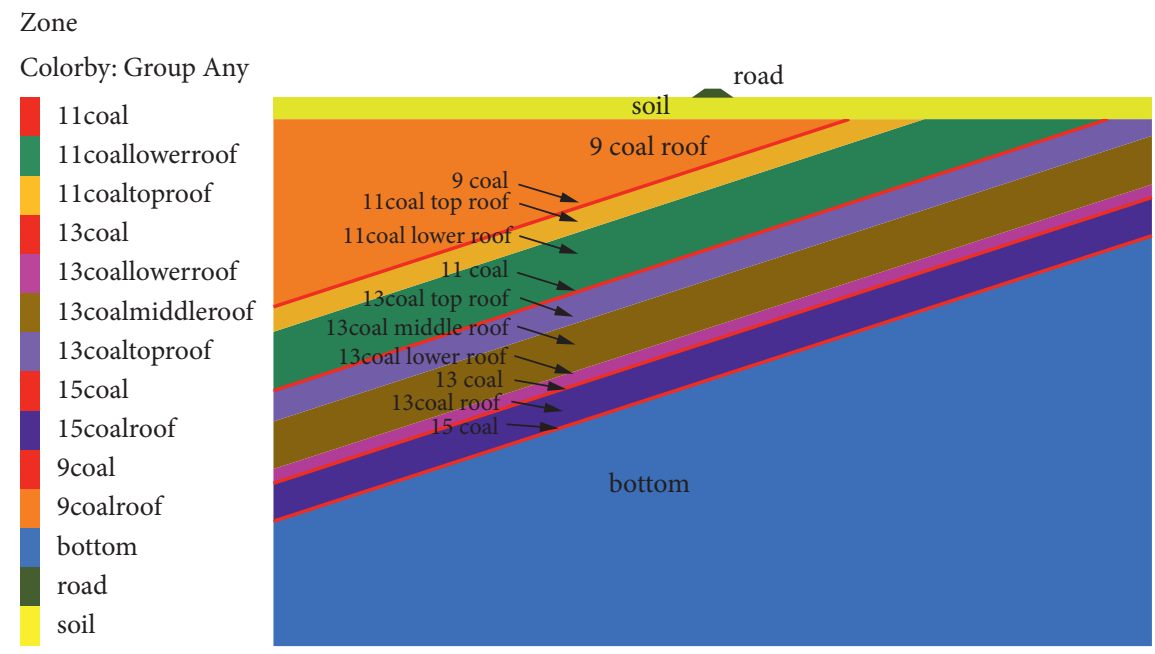

Figure 3: The three-dimensional numerical model of coal goaf under railway.

TABLE 11: Rock mass mechanical parameters of filled goafs for numerical model.

\begin{tabular}{lccccc}
\hline Roof strata & $K_{v}$ & GSI & Deformation modulus $(\mathrm{GPa})$ & Cohesion $(\mathrm{MPa})$ & Friction angle $\left(^{\circ}\right)$ \\
\hline 9 coal roof sandstone and shale & 0.46 & 55.0 & 1.49 & 0.22 & 38.5 \\
11 coal top roof shale & 0.54 & 59.2 & 2.53 & 0.31 & 37.3 \\
11 coal lower roof sandstone & 0.51 & 62.0 & 4.46 & 1.71 & 49.5 \\
13 coal top roof shale & 0.65 & 70.5 & 18.06 & 1.58 & 42.7 \\
13 coal middle roof sandstone & 0.69 & 73.0 & 12.84 & 0.80 & 50.3 \\
13 coal lower roof limestone & 0.53 & 64.0 & 5.60 & 0.48 & 38.8 \\
15 coal roof shale & 0.43 & 56.6 & & & 34.7 \\
\hline
\end{tabular}

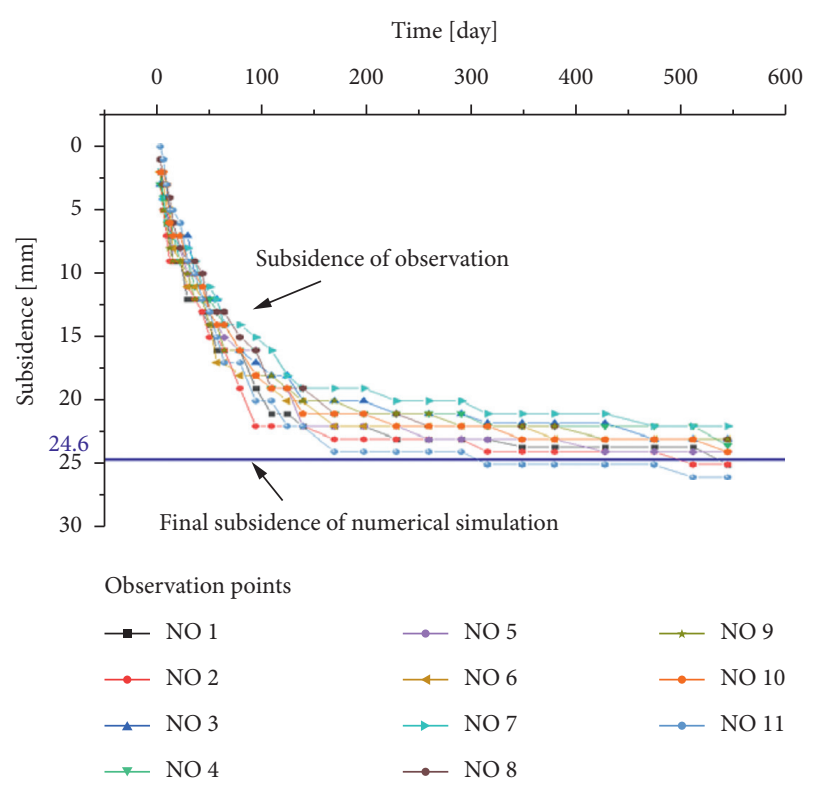

FIGURE 4: The curve of subsidence over time and the results of numerical simulation analysis.

subsidence can be effectively controlled after 9, 11, and 13 goafs are filled. The subsidence of the grouted area has been observed for a long time until it reached stability, and total observation time was 544 days. Observation points were set along the edge of the railway embankment with the distance of $20 \mathrm{~m}$. The observation points are numbered 1 to 11. The curve of subsidence over time and the results of numerical simulation analysis are shown in Figure 4.

At the beginning, the subsidence value increases quickly with time. With the continuous solidification of backfill, the mechanical parameters and strength of rock mass will increase. Hence, ground subsidence has been limited to 22 to $26 \mathrm{~mm}$, which is effectively controlled. Notably, the average of measurement value is very close to the analyzed values.

\section{Conclusion}

The traditional classification of rock mass structure is based on the volumetric joint number of rock mass, while it is difficult to accurately get deep-buried rock mass volumetric joint number. Rock mass structure is quantitatively classified by the discontinuity distance or average size of rock block $d$ and rock mass integrity index $K_{v}$ which can be easily obtained in the field test. The traditional structural surface conditions (SCR) include only roughness, weathering, and infilling, and the influence of groundwater and rock types is left out. In order to solve the problem, the ratio $\eta$ of rock mass saturated strength to dry strength is introduced, and the quantization formula of structural surface conditions is proposed. The improved geological strength index (GSI) system is adapted to all types of deeply buried rock masses. Disturbance factor $D$ is listed based on the theory of damaged material and $\mathrm{HB}$ criterion, which can reduce the influence caused by discontinuous parameters. The research has been well applied in the goaf areas. 


\section{Data Availability}

The data used to support the findings of this study are available from the corresponding author upon request.

\section{Conflicts of Interest}

The authors declare that they have no conflicts of interest.

\section{References}

[1] D. Kong, Z. Cheng, and S. Zheng, "Study on the failure mechanism and stability control measures in a large-cuttingheight coal mining face with a deep-buried seam," Bulletin of Engineering Geology and the Environment, vol. 78, no. 8, pp. 6143-6157, 2019.

[2] Y. Zhou, L. Wang, J. F. Ding, and H. Wu, "Particle flow code analysis of multi-scale jointed rock mass based upon equivalent rock mass technique," Rock and Soil Mechanics, vol. 37, no. 7, pp. 2085-2095, 2016.

[3] D. Kong, Y. Lou, S. Zheng, and S. Pu, "The characteristics of roof breaking and the law of ground pressure behavior in fully mechanized top-coal caving face with large mining height," Geotechnical \& Geological Engineering, vol. 39, no. 1, pp. 285-297, 2021.

[4] A. Palmetrom and R. Singh, "The deformation modulus of rock masses comparisons between in-situ test and indirect estimates," Tunnelling and Underground Space Technology, vol. 16, no. 3, pp. 115-131, 2001.

[5] He Wang, Ye Yuan, H. Cao, and Z. Wang, "Mechanical parameters selection of rock mass based on representative element volume," China Mining Magazine, vol. 28, no. 11, pp. 131-135, 2019.

[6] T. Zhou and J. Li, "Numerical simulation of prefabricated defects rock mass based on secondary development of FLAC3D," Safety In Coal Mines, vol. 50, no. 9, pp. 192-196, 2019.

[7] E. Hoek, C. Carranaz Torres, and B. Corkum, "Hoek-brown failure criterion-2002 edition," in Proceedings of the NarmsTac Conference, pp. 267-273, University of Toronto, Toronto, Canada, January 2002.

[8] S. Hu, "Estimation of rock mass parameters based on quantitative GSI system and Hoek-Brown criterion," Rock and Soil Mechanics, vol. 32, no. 3, pp. 861-866, 2011.

[9] K. Xia, C. Chen, X. Liu, and Y. Zheng, "Estimation of rock mass mechanical parameters based on ultrasonic velocity of rock mass and hoek-brown criterion and its application to engineering," Chinese Journal of Rock Mechanics and Engineering, vol. 32, no. 7, pp. 1458-1466, 2013.

[10] E. Hoek and E. T. Brown, "The Hoek-Brown failure criterion and GSI - 2018 edition," Journal of Rock Mechanics and Geotechnical Engineering, vol. 11, no. 3, pp. 445-463, 2019.

[11] C. Yan and G. Xu, "Stability analysis of mined-out areas influenced by blasting vibration with Flac3D," Chinese Journal of Rock Mechanics and Engineering, vol. 24, no. 16, pp. 2894-2899, 2005.

[12] E. Hoek and E. T. Brown, Underground Excavations in Rock, Institution of Mining and Metallurgy, London, 1980.

[13] E. Hoek and E. T. Brown, "Practical estimates of rock mass strength," International Journal of Rock Mechanics and Mining Sciences, vol. 34, no. 8, pp. 1165-1186, 1997.

[14] E. Hoek and M. S. Diederichs, "Empirical estimation of rock mass modulus," International Journal of Rock Mechanics and Mining Sciences, vol. 43, no. 2, pp. 203-215, 2006.
[15] H. Sonmez and R. Ulusay, "Modifications to the geological strength index (GSI) and their applicability to stability of slopes," International Journal of Rock Mechanics and Mining Sciences, vol. 36, no. 6, pp. 743-760, 1999.

[16] Ministry of Water Resources of the PRC, Standard for Engineering Classification of Rock Mass (GB/T 50218-2014), China Planning Press, Beijing, China, 2014.

[17] Engineering Geology Handbook Editorial Board, Geological Engineering Handbook, China Building Industry Press, Beijing, China, 2018.

[18] H. Sonmez, H. A. Nefeslioglu, and C. Gokceoglu, "Determination of wJd on rock exposures including wide spaced joints," Rock Mechanics and Rock Engineering, vol. 37, no. 5, pp. 403-413, 2004.

[19] First Survey and Design Institute of the Ministry of Railway, Handbook of Railway Engineering Geology, China Railway Publishing House, Beijing, China, 1999.

[20] Ministry of Water Resources of the People's Republic of China, Standard for Engineering Classification of Soil, China Planning Press, Beijing, China, 2008.

[21] Editee et Diffusee Par I Association Francaise, Reconnaissance et seeais geotechniques denomination, description et classification des roches, Partie 1: Denomination et description, 2003.

[22] A. Palmstrom, "Characterizing rock measses by the RMI for use in practical rock engineering, part 1 : the development of the rock mass index (RMI)," Tunnelling and Underground Space Technology, vol. 11, no. 2, pp. 175-188, 1996.

[23] G. Jiang, N. Hu, G. Hong, G. Li, and G. Pang, "Determination of rock mass mechanical parameters based on quantification and correction method of GSI value," Rock and Soil Mechanics, vol. 39, no. 6, pp. 1001-1008, 2018.

[24] Y. Fu, Y. Wenhan, X. Liu, L. Miao, and W. Xie, "Deterioration rules of strength parameters of sandstone under cyclical wetting and drying in acid-based environment," Rock and Soil Mechanics, vol. 39, no. 9, pp. 3331-3339, 2018.

[25] X. Liu, D. Li, L. Zhang, and Z. Wang, "The research on the wet-dry cycl's influence on the mechanical properties and microstructure change law of shaly sandstone," Chinese Journal of Geotechnical Engineering, vol. 38, no. 7, pp. 12911300, 2016.

[26] C. Wang, C. Liu, and D. Liu, "Experimental study on volume effect of saturated fractured sandstone under uniaxial compression," Chinese Journal of Underground Space and Engineering, vol. 15, no. 5, pp. 1331-1340, 2019.

[27] Y. Chen, W. Liang, J. Yang, H. Lian, and N. Xiao, "Study on the effective stress characteristic of rough rock fractures with water pressure," Chinese Journal of Rock Mechanics and Engineering, vol. 37, pp. 3850-3860, 2018.

[28] Z. Bieniawski, Engineering Rock Mass Classifications, The Wiley-Interscience Publication, Hoboken, NJ, US, 1989.

[29] Y. Liu, Damage Evolution and Rheological Behavior of Deeo Rock Mass under Water-Rock Interaction, Central South University, Changsha, China, 2012.

[30] J. Lemaitre, "How to use damage mechanics," Nuclear Engineering and Design, vol. 80, no. 2, pp. 233-245, 1984. 